\title{
Challenges in children's enrolment to psychosocial services
}

\author{
Andre Sourander ${ }^{1}$
}

Published online: 26 March 2015

(C) Springer-Verlag Berlin Heidelberg 2015

Numerous studies mainly from Western societies have shown that only a minority of children with mental health problems receive psychosocial care [1-3]. In a Finnish time trend study including three cross-sectional cohorts of 8-year-old children born in 1981, 1991 and 1997, it was shown that while only $10 \%$ of children with a high level of psychiatric problems among those born in 1981 had contact with services, the respective figures for those born in 1991 and 1997 were 23 and $27 \%$ [3]. Although there seemed to be positive increase in enrollment to services, the majority of the latter born children with psychiatric problems nevertheless had no contact with services. There is also mounting evidence from population based birth cohort studies based on large numbers of children followed-up from childhood to adulthood showing that child mental health problems are associated with a wide range of adult adversities including psychiatric disorders, suicidality and crime [4-11]. Some studies indicate that one half of adult psychiatric disorders begin in childhood. Childhood disruptive behavior predicts early substance use, tobacco use and obesity [12-15]. Does this not mean that early identification and subsequent low threshold interventions (e.g., parenting programs for preschool children with disruptive behavior) may not only have the potential to prevent some chronic psychosocial adversities but also to have an impact on general health particularly including health issues in later life related to alcohol and tobacco use and the metabolic syndrome?

Andre Sourander

andsou@utu.fi

1 Department of Child Psychiatry, Child Psychiatry Research Centre, Turku University, Teutori 3rd floor, 20520 Turku, Finland
In this issue Marieke Nanninga and her colleques from Groningen, The Netherlands, report findings from a study including 1331 children and adolescents enrolled in psychosocial care [16]. Low family support, poor parenting skills and inconsistent discipline proved to be associated with enrolment in psychosocial care. Thus, children of families with low family social support were more likely to have psychosocial problems and these problems made enrolment in psychosocial care more likely. The authors conclude that further research is needed to assess if interventions entailing a positive effect on family social support and skills indeed leads to less enrolment in care. The authors note that no previous study had examined the association between family social support, parenting skills and children's enrolment in a broad field of psychosocial care (including preventive, social and mental health care).

Service use among preschool children with a mental problem is lower than for older school-age children [8]. A recent study published in Pediatrics and led by Lars Wichstrom from Trondheim, Norway identified socio demographic, child, parent, and day care provider variables at age 4 , which predict children's service use for mental health problems at age 7 [17]. The study indicated that the pathway towards service use among young children originates with disruptive behavior symptoms. The Trondheim study suggests that disruptive behavioral symptoms increase the probability of service use if (a) child impairment results, (b) this impairment represents a burden to parents, (c) the problems are recognized and (d) the child is judged as in need of help by the parent, and, in particular, by day care teachers. Both the study from Groningen and Trondheim address service use problems from the ecological perspective of the child's life.

Despite the high prevalence and the associated significant burden, there is an enormous gap worldwide in the 
provision of treatment for mental disorders in children. Perhaps the most challenging barrier of service delivery is the great shortage of skilled human resources to address child mental disorders in most regions of the world. Several factors such as stigma, availability and cost of services, and logistical barriers such as child care, transportation time, work schedules, or discomfort with services delivered in groups prevent many parents from enrolling in or completing child mental health programs. Furthermore, low income, limited education, maternal stress, and parental depression or other parental psychiatric disorders can prevent enrollment or interfere with program completion [1824]. There is a need of European research initiatives to find new solutions to enroll families and children at risk in interventions. Furthermore, new solutions are required to both identify children at risk early and to provide the respective families with evidence based low threshold interventions. One venue may be to use new technology (e.g., web, smart phones) and remote intervention approaches at the population level to deliver some of the interventions $[18,19]$. Finally, this needs to be done in a feasible manner and with budgets that are realistic in the current economical situation. As such, health economics should play an important role in service use research. To achieve these goals we need more and extended collaborations.

\section{References}

1. Wölfle S, Jost D, Oades R, Schlack R, Hölling H, Hebebrand J (2014) Somatic and mental health service use of children and adolescents in Germany (KiGGS-study). Eur Child Adolesc Psychiatr 23(9):753-764

2. Gyllenberg D, Gissler M, Malm H, Artama M, Hinkka-YliSalomäki S, Brown AS, Sourander A (2014) Specialized service use for psychiatric and neuro developmental disorders by age 14 in Finland. Psychiatr Serv 65(3):367-373. doi:10.1176/appi. ps. 201200544

3. Sourander A, Niemelä S, Santalahti P, Helenius H, Piha J (2008) Changes in psychiatric problems and service use among 8-yearold children: a 16-year population-based time-trend study. J Am Acad Child Adolesc Psychiatry 47(3):317-327. doi:10.1097/ CHI.0b013e318160b98f

4. Sourander A, Jensen P, Davies M, Niemelä S, Elonheimo H, Ristkari T, Helenius H, Sillanmäki L, Piha J, Kumpulainen K, Tamminen T, Moilanen I, Almqvist F (2007) Who is at greatest risk of adverse long-term outcomes? The Finnish from a Boy to a Man study. J Am Acad Child Adolesc Psychiatr 46(9):1148-1161

5. Gyllenberg D, Sourander A, Niemelä S, Helenius H, Sillanmäki L, Piha J, Kumpulainen K, Tamminen T, Moilanen I, Almqvist F (2010) Childhood predictors of later psychiatric hospital treatment: findings from the Finnish 1981 birth cohort study. Eur Child Adolesc Psychiatr 19(11):823-833. doi:10.1007/s00787010-0129-1 [Epub 2010 Sep 7]

6. Sourander A, Klomek AB, Niemelä S, Haavisto A, Gyllenberg D, Helenius H, Sillanmäki L, Ristkari T, Kumpulainen $\mathrm{K}$, Tamminen T, Moilanen I, Piha J, Almqvist F, Gould MS (2009) Childhood predictors of completed and severe suicide attempts: findings from the Finnish 1981 Birth Cohort
Study. Arch Gen Psychiatry 66(4):398-406. doi:10.1001/ archgenpsychiatry.2009.21

7. Caspi A, Moffitt TE, Newman DL, Silva PA (1996) Behavioral observations at age 3 years predict adult psychiatric disorders. Longitudinal evidence from a birth cohort. Arch Gen Psychiatr 53:1033-1039

8. Hofstra MB, van der Ende J, Verhulst FC (2002) Child and adolescent problems predict DSM- IV disorders in adulthood: a 14-year follow-up of a Dutch epidemiological sample. J Am Acad Child Adolesc Psychiatr 41:182-189

9. Kim-Cohen J, Caspi A, Moffitt TE, Harrington H, Milne BJ, Poulton R (2003) Prior juvenile diagnoses in adults with mental disorder: developmental follow-back of a prospective- longitudinal cohort. Arch Gen Psychiatr 60:709-717

10. Simonoff E, Elander J, Holmshaw J, Pickles A, Murray R, Rutter M (2004) Predictors of antisocial personality. Continuities from childhood to adult life. Br J Psychiatr 184:118-127

11. Fergusson DM, John Horwood L, Ridder EM (2005) Show me the child at seven: the consequences of conduct problems in childhood for psychosocial functioning in adulthood. J Child Psychol Psychiatr 46:837-849

12. Duarte CS, Sourander A, Nikolakaros G, Pihlajamaki H, Helenius $\mathrm{H}$, Piha J, Kumpulainen $\mathrm{K}$, Moilanen I, Tamminen $\mathrm{T}$, Almqvist F, Must A (2010) Child mental health problems and obesity in early adulthood. J Pediatr 156(1):93-97. doi:10.1016/j. jpeds.2009.06.066 [Epub]

13. Niemelä S, Sourander A, Pilowsky DJ, Susser E, Helenius H, Piha J, Kumpulainen K, Moilanen I, Tamminen T, Almqvist F (2009) Childhood antecedents of being a cigarette smoker in early adulthood. The Finnish 'From a Boy to a Man' Study. J Child Psychol Psychiatr 50(3):343-351. doi:10.1111/j.14697610.2008.01968.x [Epub 2009 Jan 21]

14. Goodwin RD, Sourander A, Duarte CS, Niemelä S, Multimäki P, Nikolakaros G, Helenius H, Piha J, Kumpulainen K, Moilanen I, Tamminen T, Almqvist F (2009) Do mental health problems in childhood predict chronic physical conditions among males in early adulthood? Evidence from a community-based prospective study. Psychol Med 39(2):301-311. doi:10.1017/ S0033291708003504 [Epub 2008 May 28]

15. Niemelä S, Brunstein-Klomek A, Sillanmäki L, Helenius H, Piha J, Kumpulainen K, Moilanen I, Tamminen T, Almqvist F, Sourander A (2011) Childhood bullying behaviors at age eight and substance use at age 18 among males. A nationwide prospective study. Addict Behav 36(3):256-260. doi:10.1016/j.addbeh.2010.10.012 [Epub 2010 Nov 10]

16. Nanninga M, Jansen DEMC, Knorth EJ, Reijneveld SA (2014) Enrolment of children and adolescents in psychosocial care: more likely with low family social support and poor parenting skills. Eur Child Adolesc Psychiatr. doi:10.1007/ s00787-014-0590-3

17. Wichstrøm L, Belsky J, Jozefiak T, Sourander A, Berg-Nielsen TS (2014) Predicting service use for mental health problems among young children. Pediatrics 133(6):1054-1060. doi:10.1542/peds.2013-3184 [Epub 2014 May 12]

18. McGrath PJ, Sourander A, Lingley-Pottie P, Ristkari T, Cunningham C, Huttunen J, Filbert K, Aromaa M, Corkum P, HinkkaYli-Salomäki S, Kinnunen M, Lampi K, Penttinen A, Sinokki A, Unruh A, Vuorio J, Watters C (2013) Remote populationbased intervention for disruptive behavior at age four: study protocol for a randomized trial of Internet-assisted parent training (Strongest Families Finland-Canada). BMC Public Health 13:985. doi:10.1186/1471-2458-13-985

19. McGrath PJ, Lingley-Pottie P, Thurston C, MacLean C, Cunningham C, Waschbusch DA, Watters C, Stewart S, Bagnell A, Santor D, Chaplin W (2011) Telephone-based mental health interventions for child disruptive behavior or anxiety disorders: 
randomized trials and overall analysis. J Am Acad Child Adolesc Psychiatr 50:1162-1172

20. Cunningham CE, Boyle M, Offord D, Racine Y, Hundert J, Secord M, McDonald J (2000) Tri-ministry study: correlates of school-based parenting course utilization. J Consult Clin Psychol 68:928-933

21. Kazdin AE, Holland L, Crowley M (1997) Family experience of barriers to treatment and premature termination from child therapy. J Consult Clin Psychol 65:453-463

22. Barkley RA (2000) Commentary on the multimodal treatment study of children with ADHD. J Abnorm Child Psychol 28:595-599
23. Lingley-Pottie P, McGrath PJ, Andreou P (2013) Barriers to mental health care: perceived delivery system differences. ANS Adv Nurs Sci 36:51-61

24. Cunnigham CE, Deal K, Rimas H, Buchanan DH, Gold M, Sdao-Jarvie K, Boyle M (2008) Modeling the information preferences of parents of children with mental health problems: a discrete choice conjoint experiment. J Abnorm Child Psychol 36:1123-1138 